
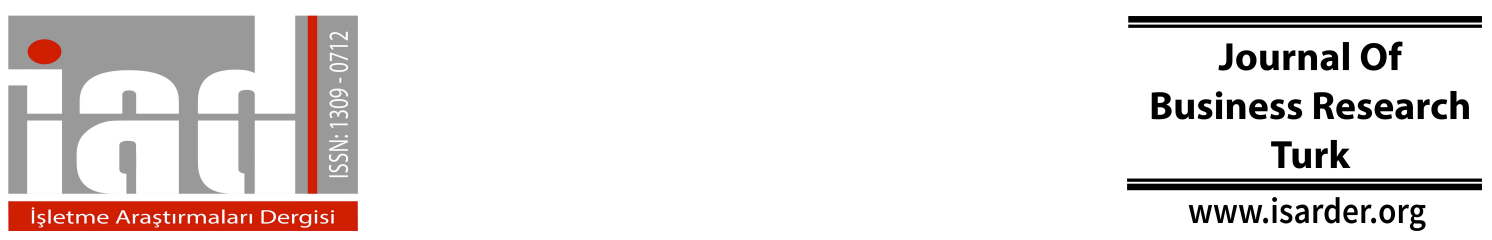

\title{
An Overview of Franchising in The Hospitality Industry of Turkey
}

\author{
Orhan YABANCI \\ Eskişehir Osmangazi University \\ Faculty of Tourism \\ Department of Travel Management \\ and Tour Guidance \\ Eskişehir, Turkey \\ oyabanci@ogu.edu.tr
}

\author{
Ali ERBAŞ \\ Eskişehir Osmangazi University \\ Faculty of Tourism \\ Department of Gastronomy \\ and Culinary Arts \\ Eskişehir, Turkey \\ aerbas@ogu.edu.tr
}

\begin{abstract}
Tourism is regarded as one of the fastest growing industries of our time. International hotel chains seem to contribute this development to a great amount. These hotels invest in Turkey since 1950s. Recently, these investments seem to be made majorly as franchises. Today, franchising seems to be one of the major strategies to enter global markets. And the system is popular because of its organisational and financial advantages. Although Franchising is adopted and frequently used in tourism industry, there are not (if any) any studies investigating facts and figures of the subject. In this regard, herein it is aimed to overview the current state of franchising in the Turkish tourism industry. Therefore, international hotel chains operating through Franchising in the hospitality industry of Turkey are reviewed in this study. Findings of the study suggest that international hotel chains aiming to expand in the market of Turkey prefer franchising as the major growth strategy to any other.
\end{abstract}

Keywords: Turkey, hospitality industry, hotel chains, franchise, franchising

\section{Introduction}

Tourism is one of the major social and economic phenomena of modern times (Sharpley, 2004, p. 11). And in years, it has become one of the fastest growing industries (Edgel, Allen, Swanson and Smith, 2014, p. 182; World Tourism Organisation [UNWTO], 2015a). With the increase of numbers of the destinations, now, tourism is one of the key industries by providing socio-economical development, job opportunities and infrastructural development (World Tourism Organisation [UNWTO], 2015b, p. 2). According to 2014 data of World Tourism Organisation, tourism receipts reached US\$ 1159 billion (euro 873 bn) worldwide in 2013 (UNWTO, 2015b, p. 5). In the year of 2014, the receipts reached US\$ 1245 billion (euro 937 bn) with an increase of 3.7\% (World Tourism Organisation [UNWTO], 2015c, p. 2). It is predicted that by 2030 tourist arrivals will reach to US\$ 1.8 billion with an increase of $3.3 \%$ in the period of 2010-2030 (UNWTO, 2015b, p. 13; UNWTO, 2015c, p. 14). 
As throughout the world, tourism industry keeps growing numerically in Turkey. According to statistics, Turkey was in the sixth row in the year of 2013 with a growth of $5.9 \%$ compared to 2012. (UNWTO, 2015b, p. 6). In the year of 2014, it maintained its position with a growth of $5.3 \%$ (UNWTO, 2015c, p. 6). On the other hand, tourism receipt in 2014 reached about US\$ 34 billion with a growth of $6.2 \%$ compared to previous year (Kültür ve Turizm Bakanlığ 1 [KTB], 2015a). And in the three quarter of 2015 , the receipt reached about US\$24.8 billion (KTB, 2015a).

Bradach (1998) states that chains represent one of the dominant organisational forms of our time. As stated by Collins Dictionaries (2015), a hotel chain is a group of hotels which belong to the same company or owner, or, are associated in some way. Relatively, an international hotel chain can be defined as a hotel chain that operates in more than one country.

Hotel chains seem to be playing a part in the development of tourism industry. International hotel chains have been in Turkey since 1950s (Türksoy, Kaygalak and Koçak, 2013, p. 99). The first hotel chain that came to Turkey was Hilton (1955), Club Med (1966), Accor (1970), InterContinental (1971) and Starwood (1975) (Türkiye'de Yabancı Marka Sayısı da Otel Grubu da Hizla Artiyor, 2014, p. 9). Notably in recent years, international hotel chains invest in Turkey vastly. According to recent researches, hotel chains has doubled in number in the last decade; in 2011, foreign groups had 142 hotels in Turkey, whereas they had 72 hotels in the year of 2001 (Türkiye'de Zincir ve Grup Oteller, 2012, pp. 6-10). Today this number has much advanced. Perhaps one of main reasons of this is the act of "Dogrudan Yabancı Yatırımlart Teşvik" (no. 4875) issued in 2003 by the Turkish Parliament. By this act, finances obtained through licence, management and suchlike agreements has been allowed to be transferred abroad freely (E-mevzuat, 2015).

International hotel chains invest in Turkey more than half century. These investments are generally made as full ownership, strategic management, management agreements and franchising. Franchising constitutes a vital facet of the chains (Bradach, 1998 , p. 3). Recently, franchising is one of the most popular and adopted growth strategies of tourism industry. However, this is not the case for the literature. There are no (if any) researches that study the subject. Franchising as a leading intellectual property-leveraging strategy (Sherman, 2004, p. 11) and a rising trend in tourism needs to be reviewed and examined. Thus, the purpose of this study is to overview the state of franchising in the Turkish tourism industry. In order to underpin the aim of the study, a basic statistical analysis was carried out to see if franchising is the major spread and growth strategy of international hotel chains in the market of Turkey. The study is expected to contribute to literature by drawing a holistic up-to-date portrait of the subject.

\section{Literature review}

The roots of the word franchising is accepted to be the French words; franc, francher, franchir or affranchir that mean "free from servitude" (Khan, 1999, p. 2; Kırca, 1997, p. 3; Şoğur, 1993, p. 3). The concept was set in literature with its English definition as "franchising" (Kırca, 1997, p. 3; Şoğur, 1993, p. 3).

There are various definitions of franchising in the literature. Taylor (2000) renders the reason of this partly to disparate types of business relationships to which this term 
has been applied. As defined by Entrepreneur (2015) franchising is " $a$ continuing relationship in which a franchisor provides a licensed privilege to the franchisee to do business and offers assistance in organizing, training, merchandising, marketing and managing in return for a monetary consideration". On the other hand International Franchise Association [IFA] (2015) defines franchising as " $a$ method for expanding a business and distributing goods and services through a licensing relationship". There can be inferred that the common point of these two definitions is the term "relationship". It is stated that a close relationship between franchisor and franchisee is crucial in franchising (Arslan, 2006, p. 3). The success to a great amount is bound to the effective management of this relationship (Arslan, 2006, p. 3; IFA, 2015; Sherman, 2004, p. 16).

The primitive practices of franchising date back to the Middle Ages (Arslan, 2006, p. 41; Birkeland, 2002, p. 1; Kirca, 1997: 4). But in modern sense, franchising starts with Isaac Singer's permission to independent sellers in 1851 to sell his sewing machines in a specific region in return a fee (Arslan, 2006, p. 41; Khan, 1999, p. 10; Kurca, 1997, p. 5; Saban, 1997, p. 15). Afterwards, in 19th and 20th centuries, automobile, petrol and beverage producers in the United States adopted franchising that led it to gain its popularity (Kırca, 1997, p. 5; Saban, 1997, p. 16). 1950s are the years that franchising boomed and gained prevalence in various industries including service (Arslan, 2006, p. 43; Khan, 1999, p. 11; Taylor, 2000a, p. 4). Blair and Lafontaine (2005), states that franchising now has become a part of the daily life.

Franchising in Turkey is a young concept when compared to the United States and Europe (Arslan, 2006, p. 48; Saban, 1997, p. 18). The official regulations to alleviate bureaucratic barriers towards foreign investors and portfolio in 1980s drove attention of franchisors to Turkey (Akademiktisat, 2015; Nart, 2005 p. 126). American fast food chain McDonalds is recognized as the first franchisor that brought franchising to Turkey at the end of 1980s (Arslan, 2006, p. 48; Saban, 1997, p. 18). After that on, a large number of international chains started franchise operations in Turkey (Saban, 1997, p. 18). Apart from food; automobile, white goods and cosmetics were the industries that used this method (Arslan, 2006, p. 48). In 1991, with the foundation of Ulusal Franchising Derneği (UFRAD), practices were started to advertise and perform franchising efficiently (Saban, 1997, p. 18). Currently, UFRAD has 174 members 3 of which are hotel brands. These are Days Inn, Hawthorn Suites by Wyndham and TRYP by Wyndham all of which are brands of Wyndham Hotel Group.

\section{Franchising as a system}

There are various approaches in the literature that consider franchising as a system (figure 1). According to a definition, franchising is "a system based on close and constant collaboration between legally and financially independent companies in which goods and/or technology is marketed and the franchisor grants privileges the franchisee to operate its business appropriately" (Saban, 1997, p. 1). Relatively, Arslan (2006) define franchising as "an integrated marketing system based on an agreement".

There are two main parts in franchising system; the franchisor and the franchisee. A franchisor is the owner and permanent rights-holder of a brand and business while a franchisee is just the temporary right user of a brand and business. Franchising starts with the sing of a franchise agreement between the franchisor and the franchisee that brings both some legal responsibilities and rights inter se (Arslan, 2006, p. 11). 
Franchise agreements usually require a one-off franchise, licence or copyright fee in return for the transfer of franchise (Business Dictionary, 2015; Saban, 1997, p. 46). Franchise contracts generally end upon expiration, extraordinary annulment, death, loss of licence and bankruptcy (Arslan, 2006, p. 13).

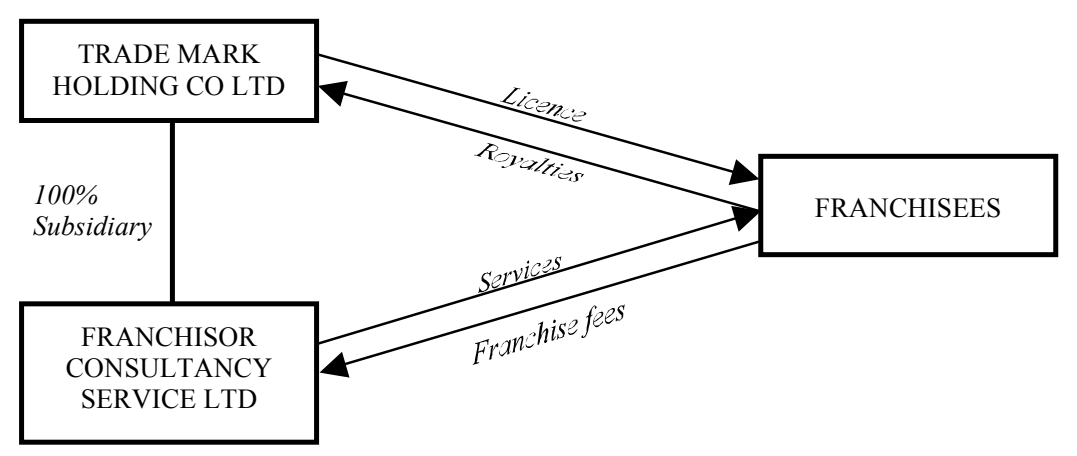

Figure 1: Franchising system (source: Adams and Prichard-Jones, 1987, p. 251)

\section{Why and why not franchising?}

Franchising has gained prevalence as a popular marketing and distribution channel option in the last sixty five years (Fulop, 2000, p. 25). There has been a central question among researchers about why many businesses chose to expand by means of franchising rather than by means of company-owned units (Taylor, 2000a, p. 7). The answer concentrates on two common theories; "resource scarcity" and "agency". According to resource scarcity; firms prefer franchising in order to reduce the levels of financial and organisational risks, transfer franchisee risk and use external resources just except using internally generated resources (Castrogiovanni, Combs and Justis, 2006, p. 29; Taylor, 2000a, p. 8). On the other hand Agency theory suggests that franchisors through franchising can ensure monitoring of agent behaviour and incentives tie to agent outputs at minimum costs (Castrogiovanni, Combs and Justis, 2006, p. 30; Taylor, 2000a, p. 9).

Franchise has many advantages for both franchisor and franchisee that are reinforced by socio-economic influences and involvement of interested third parties (Fulop, 2000, p. 25). As Khan (1999) states franchising is a win-win situation if performed properly. This method of operation can be far more efficient and profitable than an owned enterprise (Keup and Keup, 2012, p. 73). Franchising, for an entrepreneur can be a cost-efficient and systematic marketing and growth strategy without having to invest or affiliate directly while it can be an opportunity to own a proven concept, product or business format with a minimum financial risk for a franchisee (Khan, 1999, pp. 5-6). Thus, businesses that adopt franchise system can enter markets rapidly, can share the risks in the growth process, can keep the control of marketing and distribution channels and can get more profit opportunity (Arslan, 2006, p. 95; Hoffman and Preble, 1993, p. 35; Norman, 2006, p. 1). Besides, franchising can provide the company with motivation, dedication and initiative other than capital input (Fulop, 2000, p. 29).

Notwithstanding the many benefits of franchising for both franchisor and franchisee, it is not easy to manage this concept (Fulop, 2000, p. 29). As Sherman (2011) states franchising may not be a method of business growth for everyone; it is 
appropriate for only certain kind of companies. In a decentralised operation like franchising, it is hard enough to maintain standard service and keep a consistent public image in the network (Fulop, 2000, p. 29). On the other hand, responsibilities and control procedures in the franchise system may restraint administrative decisions range of the franchisee (Lashley, 2000, p. 109). According to Adams and Prichard-Jones (1987), the main danger for a franchisor is the risk to be liable for the debts of its franchisee in case of any bankruptcy. This is the case for hotel franchise. Hotels are complicated investments and selecting a proper franchise entails exhaustive research by an investor (Rushmore and Bagley, 2014, p. 2).

\section{Hotel franchising}

Tourism researchers define franchising "as a covenant in which franchisor entitles a franchisee to use franchisor's company name and to market its products"; thus it makes no difference from the franchising in other industries (Pender, 2000, p. 220). In modern sense, hotel franchising has existed since the foundation of Holiday Inn's franchise system of its own in 1954 (Cunill, 2009, p. 113; Taylor, 2000b, p. 171). However, the earliest example of hotel franchising is claimed to be the permission given to use Cesar Ritz's name to be attached to some hotels located in New York, Boston, Montreal, Lisbon and Barcelona in 1907 (Taylor, 2000b, p. 171).

Lately, tourism industry has been experimenting with the concept of franchising (Pender, 2000, p. 220). This concept has become significant in hospitality industry for about thirty five years (Taylor, 2000a, p. 4). Today, it can be clearly seen that the largest hotel groups have adopted the concept of franchising (see table 1). For example, InterContinental Hotels Group (2015a) state that franchising is the largest part of their business with the franchise agreements signed with more than 3900 hotels. Top ten groups such as Wyndham, Choice, InterContinental and Hilton mostly prefer franchising as their way of growth to other methods (see table 1). In the ranking of Top Global Franchises Rankings 2015 of Franchise Direct (2015), hotel chains such as Wyndham Hotels \& Resorts (rank 9th), InterContinental Hotels \& Resorts (rank 15th), Hilton Hotels \& Resorts (rank 16th), Marriott International (rank 18th) and Choice Hotels (rank 23rd) take place at the top ranks of list. These all of the above indicate how franchising has become a phenomenon in tourism. On the other hand, it seems that groups that adopt franchise system most are generally the largest hotel groups therewithal (see table 1).

Given before, the state of hotel franchising in Turkey is obscure. There are no (if any) significant academic studies focusing on the subject of franchising in the hospitality industry of Turkey. 
Table 1: Largest hotel groups and hotel franchise groups (source: Hotel Online, 2015*; Hotels, 2015**)

\begin{tabular}{|c|c|c|c|c|c|c|}
\hline \multicolumn{5}{|c|}{ The Largest Hotel Groups* } & \multirow{2}{*}{\multicolumn{2}{|c|}{$\begin{array}{l}\text { The Largest Hotel Franchisors** } \\
2014 \text { (End of 2013) }\end{array}$}} \\
\hline & 1st Jan & ary 2015 & 1st Jan & ry 2014 & & \\
\hline Groups & Hotels & Rooms & Hotels & Rooms & Groups & Franchises \\
\hline Wyndham Hotel Group & 7645 & 660826 & 7485 & 645423 & Wyndham Hotel Group & 7425 \\
\hline Choice Hotels International & 6376 & 504808 & 6340 & 506058 & Choice Hotels International & 6340 \\
\hline $\begin{array}{l}\text { InterContinental Hotels } \\
\text { Group }\end{array}$ & 4840 & 710295 & 4697 & 686873 & $\begin{array}{l}\text { InterContinental Hotels } \\
\text { Group }\end{array}$ & 3955 \\
\hline Hilton Worldwide & 4278 & 708268 & 4073 & 672083 & Hilton Worldwide & 3420 \\
\hline Marriott International & 4117 & 701899 & 3854 & 662821 & Marriott International & 2672 \\
\hline Best Western & 3900 & 302144 & 4046 & 314318 & Magnuson Hotels & 1865 \\
\hline Accor Hotels Group & 3717 & 482296 & 3576 & 461719 & Accor Hotels Group & 1402 \\
\hline Home Inns & 2609 & 296075 & 2180 & 256555 & Home Inns & 1365 \\
\hline Jin Jiang & 2208 & 241910 & 918 & 128952 & GreenTree Inns & 1171 \\
\hline Starwood Hotels \& Resorts & 1207 & 346599 & 1161 & 339243 & Vantage Hospitality Group & 1102 \\
\hline
\end{tabular}

\section{Methodology}

The guiding central question of this study is: "what is the (current) state of the franchising system in the hospitality industry of Turkey?" Starting with a general literature review an underpinning further statistical research was carried out to attest if franchising is a prevailing expanding strategy in the Turkish hospitality industry. Thus, the study focuses on top international hotel chains which decide franchising as a growth strategy throughout the world as well as Turkey. The chains to be review herein were specified as Wyndham Hotel Group, Choice Hotels International, InterContinental Hotels Group, Hilton Worldwide, Marriott International, Magnuson Hotels, Accor Hotels Group, Home Inns, GreenTree Inns and Vantage Hospitality Group (see table 1). However, even though they are not in the top ten list groups such as Best Western, Starwood Hotels \& Resorts and Carlson Rezidor Hotel Group were included in the research as they do active business by means of franchise in Turkey.

In order to explore the affiliations of the mentioned hotel chains have; two main research questions were specified. These are as follows;

1. How many hotels (in total) do you have in Turkey?

2. How many of those are franchised?

Data for the research was provided though phone and the internet. As Duffy (2000) states, users can, via the internet, access numerous information about organisations and individuals across the world in a fast and flexible way. Therefore, preliminary research was done by means of the internet. At the outset, websites of the hotel groups were visited to explore about their any commercial affiliations in Turkey. Next, Europe, Middle East or Turkey representatives of the groups those detected to have any hotel brand in Turkey were contacted by both phone and e-mail to consult about their business in Turkey. The very most of the spokesmen kindly favoured with their answers and feedbacks. The answers and feedbacks matched with the preliminary research. However, upon the no-reply, or partly refusal of two hotel groups to provide information about their franchise affiliation in Turkey, as an alternative method, each 
existing hotel of these groups in Turkey was called by phone or was searched through the internet to explore if the branch is a franchise.

\section{Findings}

Brands mentioned afore, 13 hotel groups were investigated in the study (see table 2 ); one of these is Hilton. The company operates in 97 countries with more than 4,500 hotels, and with more than 10 upscale and luxury segment brands across the world (Hilton Worldwide, 2015). Focusing on Turkey, Hilton currently has 41 properties (around $0.9 \%$ ) in operation and 29 to be opened in the future. 39 of these are franchised $(55.7 \%)$ and the rest are managed (44.3\%). The group expand in the Turkish market with the brands of Hilton Garden Inn (13 prop., 31.7\%), Hilton (12 prop., 29.2\%), Double Tree by Hilton (9 prop., 21.9\%), Hampton by Hilton (6 prop., 14.6\%) and Conrad (1 prop., 2.4\%). These hotels are dispersed over the provinces of İstanbul (14 prop., 34.1\%), İzmir (3 prop., 7.3\%), Ankara (2 prop., 4.8\%), Bursa (2 prop., 4.8\%), Muğla (2 prop., 4.8\%), Adana (2.4\%), Diyarbakır (2.4\%), Erzincan (2.4\%), Gaziantep $(2.4 \%)$, Kayseri $(2.4 \%)$, Kocaeli $(2.4 \%)$, Konya (2.4\%), Kütahya (2.4\%), Malatya (2.4\%), Mardin (2.4\%), Mersin (2.4\%), Ordu (2.4\%), Samsun (2.4\%), Şanlıurfa (2.4\%), Çorlu (2.4\%), Trabzon (2.4\%), Aydın (2.4\%) and Nevşehir (2.4\%). As can be educed from the above, the group have preferred to grow in Turkey mostly through their upscale (22 prop., 53.6\%), upper-upscale (12 prop., 29.2\%) and upper-midscale (6 prop., 14.6\%) brands, or as their own classification, through their "full-service hotels and resorts" (21 prop., 51.2\%) and "focused-service hotels" (19 prop., 46.3\%). On the contrary, luxury segment brands of the group are rare (1 prop., 2.4\%) in Turkey.

Wyndham the worlds' largest hotel company based on number of hotels serves in 71 countries with approximately 7,760 properties with a 15 brands portfolio (Wyndham Worldwide, 2015). This corporation already have 37 operating hotels (around $0.4 \%$ ) and 11 more will be opened in Turkey. All of these are franchised. More, Wyndham will open applications in the years of 2015, 2016 and 2018 for 8 more franchised hotels. On the other hand, the group have signed 10 years-valid development agreements for 80 hotels with 3 franchisees in Turkey. Currently, they operate in Turkey with the brands of Ramada (30 prop., 81\%), Wyndham Grand (4 prop., 10.8\%), Wyndham (2 prop., $5.4 \%$ ) and TRYP by Wyndham (1 prop., 2.7\%) spread over the provinces of İstanbul (18 prop., 48.6\%), İzmir (4 prop., 10.8\%), Antalya (3 prop., 8.1\%), Ankara (2 prop., $5.4 \%$ ), İzmit (2.7\%), Tekirdağ (2.7\%), Uşak (2.7\%), Aydın (2.7\%), Muğla (2.7\%), Nevşehir (2.7\%), Adana (2.7\%), Elazı̆g (2.7\%), Kahramanmaraş (2.7\%) and Malatya (2.7\%). Wyndham, in Turkey, has chosen to expand by its midscale (30 prop., 81\%), upper-upscale (4 prop., $10.8 \%$ ), upscale ( 2 prop., $5.4 \%$ ) segments and infrequently by its upper-midscale (1 prop., 2.7\%) segment.

French origin hotel chain Accor, with its more than 15 brands, has currently 3,792 hotels in 92 countries worldwide (Accor Hotels, 2015a; Accor Hotels, 2015b). In Turkey, Accor has opened 21 hotels (around 0.5\%) till now, and will open 7 more in the near future. 5 of these are franchise one of which is already in use. Currently, the group have 6 brands in Turkey; İbis (10 prop., 47.6\%), Novotel (5 prop., 23.8\%), Mercure (3 prop., 14.2\%), MGallery (4.7\%), İbis Styles (4.7\%), Mama Shelter (4.7\%) which are located in the provinces of İstanbul (9 prop., 42.8\%), Konya (2 prop., 9.5\%), Kayseri (2 prop., 9.5\%), Gaziantep (2 prop., 9.5\%), İzmir (4.7\%), Bursa (4.7\%), Eskişehir (4.7\%), Ankara (4.7\%), Trabzon (4.7\%) and Adana (4.7\%). As can be concluded, Accor has 
grown in Turkey through its economy (11 prop., 52.3\%) and midscale (9 prop., $42.8 \%$ ) segments. For now, up-segment brands of the group are not common (1 prop., $4.7 \%$ ) in Turkey.

Belgian origin Carlson Rezidor has an expanding portfolio of more than 1,370 hotels in over 110 countries with its 7 brands (Carlson Rezidor, 2015). It was reported that the group have 20 hotels in Turkey, 8 of which are franchises. Currently, the group have 12 operating hotels (around $0.8 \%$ ) under a limited amount of brands of Radisson Blu (11 prop., 91.6\%) and Park Inn (1 prop., 8.3\%) that are upper-upscale (11 prop., $91.6 \%$ ) and upper-midscale (1 prop., 8.3\%) segments. These hotels are located in the provinces of İstanbul (8 prop., 66.6\%), İzmir (8.3\%), Ankara (8.3\%), Kayseri (8.3\%) and Mersin (8.3\%). More upper-midscale hotels are to come soon.

British hotel company InterContinental has more than 4,900 hotels and more than 10 brands in nearly 100 countries (InterContinental Hotels Group, 2015b). The group was reported to have 20 properties (around $0.4 \%$ ) in Turkey, all franchise, and 18 of which are already in operation. On the other hand, 2 more hotels are to open soon in 2016. With the brands of Holiday Inn (9 prop., 50\%), Crowne Plaza (6 prop., 33.3\%), Holiday Inn Express (2 Prop., 11.1\%) and InterContinental (1 Prop., 5.5\%), the group has preferred to grow in Turkey in the provinces of İstanbul (10 prop., 55.5\%), Ankara (3 prop., 16.6\%), Bursa (2 prop., 11.1\%), Manisa (5.5\%), Antalya (5.5\%) and Gaziantep (5.5\%). The group has concentrated on the Turkish market with its upper-midscale (11 prop., 61.1\%), and upscale (6 prop., 33.3\%) segments. The luxury segment of the company is of a limited amount (1 prop., $5.5 \%$ ).

Best Western International is a global network of 4,100 hotels with a 7 brands portfolio in more than 100 countries (Best Western, 2015). At the present, the group have 18 properties $(0.4 \%)$ in Turkey, which are all franchise. Best Western has expanded in the market with the brands of midscale segment Best Western ( 9 prop., 50\%), upscale segment Best Western Premier (5 prop., 27.7\%) and upper-midscale segment Best Western Plus (4 prop., 22.2\%). The hotels are spread over the provinces of İstanbul (12 prop., 66.6\%), İzmir (3 prop., 16.6\%), Ankara (1 prop., 5.5\%), Antalya (1 prop., 5.5\%) and Gaziantep (1 prop., 5.5\%).

Basically the up-segment brands company Starwood has more than 1,270 properties, 10 brands, and a partnership with Design Hotels, in 100 countries (Starwood Hotels, 2015). The group have 15 operating hotels (around 1.1\%) in Turkey, 7 of which are franchise and the rest managed. With a spectrum of brands of Sheraton (7 prop., 46.6\%), The Luxury Collection (2 prop., 13.3\%), Four Points by Sheraton (2 prop., $13.3 \%$ ), The St. Regis (1 prop., 6.6\%), W (1 prop., 6.6\%), Le Meridien (1 prop., 6.6\%) and Aloft (1 prop., 6.6\%) Starwood has been serving in the provinces of İstanbul (7 prop., 46.6\%), Bursa (2 prop., 13.3\%), Ankara (2 prop., 13.3\%), Antalya (1 prop., 6.6\%), İzmir (1 prop., 6.6\%), Samsun (1 prop., 6.6\%) and Adana (1 prop., 6.6\%). The company has been doing business through their upper-upscale ( 8 prop., 53.3\%), luxury (4 prop., 26.6\%) and upscale (3 prop., 20\%) segments in the country.

Marriott International is a global lodging company with more than 4,200 hotels in 79 countries with a wide range of brand portfolio (Marriott, 2015). Majorly up-segment brands company Marriott has 12 hotels (around $0.2 \%$ ) in operation currently and 1 more is to be opened soon. 8 of those are franchised and 5 are managed. The company has been operating with its upper-upscale segment Renaissance (5 prop., 41.6\%) and 
Marriott (2 prop., 16.6\%), with its luxury segment JW Marriott (1 prop., 8.3\%), The Ritz-Carlton (1 prop., 8.3\%) and Edition (1 prop., 8.3\%), and with its upscale segment Courtyard (1 prop., 8.3\%) and AC (1 prop., 8.3\%) in the Turkish market. These upsegment hotels are spread over the provinces of İstanbul (8 prop., 66.6\%), İzmir (8.3\%), Antalya (8.3\%), Ankara (8.3\%) and Erzurum (8.3\%).

Choice Hotels International is one of the largest hotels chain with more than 6,300 hotels and about 10 brands in more than 35 countries (Choice Hotels, 2015). However, Choice is a newly growing company in the Turkey. The company, currently, has just 1 property (around $0.01 \%$ ) under the midscale brand of Clarion which is a franchise hotel located in İstanbul. The company has signed franchise agreements for 2 more Clarion Hotels planned to be opened in same the city soon.

Some of the largest hotel franchise companies in the world such as Magnuson, Home Inns, GreenTree and Vantage, the other four samples of the study, were detected to have no investments in Turkey.

Table 2: Hotels and franchises in Turkey of the largest international hotel groups

\begin{tabular}{|l|l|l|l|}
\hline \multicolumn{4}{|c|}{ Hotels in Turkey of The Largest Groups in 2015 } \\
\hline Groups & Hotels * & Franchises ** & Franchises Percentage (\%) \\
\hline Hilton Worldwide & 70 & 39 & 55.7 \\
\hline Wyndham Hotel Group & 48 & 48 & 100 \\
\hline Accor Hotels Group & 28 & 5 & 17.8 \\
\hline Carlson Rezidor Hotel Group & 20 & 8 & 40 \\
\hline InterContinental Hotels Group & 20 & 20 & 100 \\
\hline Best Western & 18 & 18 & 100 \\
\hline Starwood Hotels \& Resorts & 15 & 7 & 46.6 \\
\hline Marriott International & 13 & 8 & 61.5 \\
\hline Choice Hotels International & 3 & 3 & 100 \\
\hline Magnuson Hotels & 0 & 0 & 0 \\
\hline Home Inns & 0 & 0 & 0 \\
\hline GreenTree Inns & 0 & 0 & 0 \\
\hline Vantage Hospitality Group & 0 & 0 & 0 \\
\hline
\end{tabular}

* Sum of hotels open and hotels to be opened. ** Sum of franchised hotels open and franchised hotels to be opened.

It can be concluded from the data above that most of the world's largest hotel chains prefer to invest in Turkey. The percentage of the investments, upcoming properties excluded from calculation, change from around 0.01 to around 1.1, with an average of about 0.5 . These investments have been taking place chiefly in the provinces of İstanbul (49.7\%), İzmir (8\%), Ankara (7.4\%), Antalya (4\%), Bursa (4\%) and Gaziantep (2.8\%). The rest (24\%) are dispersed over the other provinces mentioned above. On the other hand, the investments are mostly made through midscale $(28 \%)$, upper-upscale $(24 \%)$, upscale $(22.8 \%)$ brand segments. Upper-midscale, economy and the least luxury segments occupy about 25 per cent.

Depending on the statistics, it can be remarked that franchising is a matter for the Turkish Tourism. Data obtained through the research indicate that there are 235 properties in total of the international hotel chains sampled in this study and 156 of those were detected to be franchised (table 1). Figure 2 shows that there is an uneven progress between the numbers of hotels and franchises. Numbers of franchises are not, 
in any shape or form, conforming to the numbers of hotels. In other words, not the all of the largest groups choose franchising as their solitary growing method in Turkey. However, it is clear that, it is considerably the principal development strategy for the most of them, particularly for groups such as Wyndham, InterContinental, Best Western and Choice with a 100 per cent. The average percentage of franchises is about 69 and the median is 61.5. A further SPSS frequency analysis was applied to the percentages $(\mathrm{n}=9)$, transformed to normality (skewness $=.005$; kurtosis $=-2.078)$, rendered the following outputs; mean $(\bar{x})=.9459$, median $(\bar{x})=.6629$, mode $($ Mo $)=1.57$ and standard deviation $(s)=.61418$. The statistics above underpin the indication of franchising being the major strategy for international hotel chains for entering and expanding in the Turkish hospitality industry.

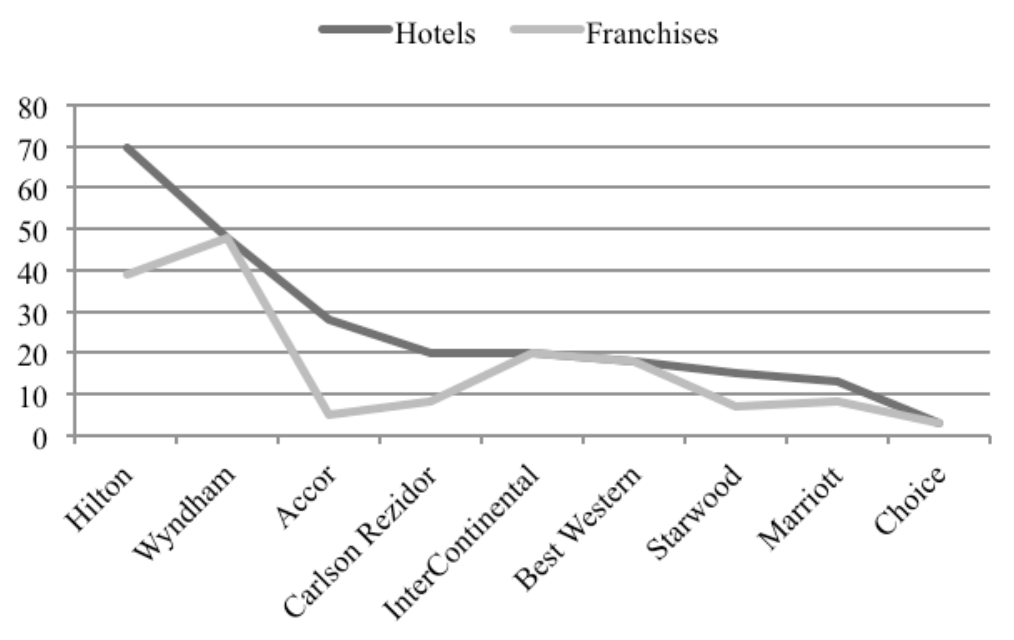

\section{Figure 2: Histogram depiction of hotels and franchises in Turkey of the largest international hotel groups}

\section{Conclusion}

As Bradach (1998) states, chains represent one of the dominant organisational forms of our time and franchising is an aspect of these chains. Lately, tourism industry, as well, has been experimenting with the concept of franchising (Pender, 2000, p. 220). This concept has become prevalent in hospitality industry for the last three or four decades (Taylor, 2000a, p. 4). Today, hotel chains seem to be playing a major part in the development of tourism industry and these have been, truly, engaged with the concept of franchising.

Despite being a challenging concept and disadvantageous at certain cases, franchising is commonly accepted as a win-win situation and a method of reducing investment risks, plus a cost-efficient systematic marketing. Pivoting on the indicators, it can be construed that it is a bona fide global growth strategy and, very likely, a practical commercial system for boosting the business in tourism of our time. Focusing on Turkey, the statistics accordingly reinforce the implication. The study findings show that the leading international hotel chains notwithstanding the lack of significant local investments (an average of about 0.5 ) tend to decide franchising as a major way of development in the Turkish hospitality industry and a method of stimulating the business. However, it was discerned that it is not the solitary growing routine. 
Management contracts and property ownerships are the two other common expansion constituents for the country. The investments chiefly have been made to the metropolises rather than seaside as resorts through midscale, upper upscale and upscale brands of the corps which indicates that global habitual expanding patterns are retained concrete or at times altered to suit to local market dynamics and diversities. On the other hand, the chains' worldwide stances on franchising as the primary growth strategy mostly corresponded with their local (considering Turkish market) ones.

Compared to the United States and Europe, franchising in Turkey is a young concept. However, in the last two decades it has much advanced in the hospitality industry of the country. It seems that regulations play a remarkable part, and perhaps are a highlight, in the case. Therefore, actions to construct the legal basis in the industry could help to shape and bolster the future of the franchising system in Turkey.

This study is limited to a framework concerning franchising in Turkey underpinned by some statistics retrieved from some of the largest international hotel chains. The study is supposed to help providing a general outline with a preview of the franchising system in the hospitality industry of Turkey. More studies to consolidate the subject should be carried out to ferret more facts out about this system and to pursue the evolution, today and tomorrow of it in the hospitality market as it has become a vital phenomenon of modern hospitality industry.

\section{References}

Accor Hotels. (2015a). Key Figures. Retrieved December 25, 2015, from http://www.accorhotels-group.com/en/group/accorhotels-company-profile/keyfigures.html

Accor Hotels. (2015b). Brand Portfolio. Retrieved December 25, 2015, from http://www.accorhotels-group.com/en/brands/brand-portfolio.html

Adams, J., and Prichard-Jones, K. V. (1987). Franchising: Practice and Precedents in Business Format Franchising, Butterworths, London.

Akademiktisat. (2015). 1980-2003 Döneminde Yabanc1 Sermayenin Türkiye’ye Gelişi ve Uygulanan Politikalar. Retrieved May 19, 2015, from http://www.akademiktisat.net/calisma/yabanci_sermaye/1980_2003_y_sermaye _fihan.htm

Arslan, K. (2006). Kobilerde Yönetim ve Pazarlama Aracı olarak Franchising, İstanbul Ticaret Üniversitesi, İstanbul.

Best Western. (2015). Why Best Western. Retrieved December 30, 2015, from http://www.bestwesterndevelopers.com/why-best-western/

Birkeland, P. M. (2002). Franchising Dreams the Lure of Entrepreneurship in America, The University of Chicago Press, USA.

Blair, R. D., and Lafontaine, F. (2005). The Economics of Franchising, Cambridge University Press, USA.

Bradach, J. L. (1998). Franchise Organizations, Harward Business School Press, USA.

Business Dictionary. (2015). Franchising. Retrieved May 19, 2015, from http://www.businessdictionary.com/definition/franchising.html 
Carlson Rezidor. (2015). Development. Retrieved December 28, 2015, from http://carlsonrezidor.com/home

Castrogiovanni, G. J., Combs, J. G., and Justis, R. T. (2006). Resource Scarcity and Agency Theory Predictions Concerning the Continued Use of Franchising in Multi-outlet Networks, Journal of Small Business Management, Vol. 44, No. 1, 27-44.

Choice Hotels. (2015). About Choice Hotels. Retrieved December 30, 2015, from https://www.choicehotels.com/about

Collins Dictionaries. (2015). Hotel Chain. Retrieved July 09, 2015, from http://www.collinsdictionary.com/dictionary/english/hotel-chain

Cunill, O. M. (2009). The Growth Strategies of Hotel Chains: Best Business Practices by Leading Companies, Routledge, NewYork.

Duffy, M. (2000). The Internet as a Research and Dissemination Resource, Health Promotion International, Vol. 15, No. 4, 349-353.

Edgel, D. L., Allen, M. D., Swanson, J., and Smith, G. (2014). Tourism Policy and Planning: Yesterday Today and Tomorrow, Routledge, Croydon.

E-mevzuat. (2015). Doğrudan Yabancı Yatırımlar Kanunu. Retrieved May 19, 2015, from http://www.mevzuat.gov.tr/MevzuatMetin/1.5.4875.pdf

Entrepreneur. (2015). Franchising. Retrieved May 19, 2015, from http://www.entrepreneur.com/encyclopedia/franchising

Franchise Direct. (2015). Top 100 Global Franchises Rankings 2015. Retrieved July 08, 2015, from http:/www.franchisedirect.com/top100globalfranchises/rankings/

Fulop, C. (2000). History and Development. Inside C. Lashley and A. Morrison (Eds.), Franchising Hospitality Services (pp. 22-43), Butterworth-Heinemann, Great Britain.

InterContinental Hotels Group. (2015a). Business Models: Franchising. Retrieved July 06, 2015, from http://development.ihg.com/europe/

InterContinental Hotels Group. (2015b). About Us. Retrieved December 29, 2015, from http://www.ihgplc.com/index.asp?pageid=2

International Franchise Association. (2015). What is a Franchise. Retrieved May 19, 2015, from http://www.franchise.org/what-is-a-franchise.

Hilton Worldwide. (2015). About Us. Retrieved December 24, 2015, from http://hiltonworldwide.com/about/.

Hoffman, R. C. and Preble, J. F. (1993). Franchising into the Twenty-first Century, Business Horizons, Vol. 36, No. 6, 35-43.

Hotel Online. (2015). Global Hotel Ranking 2015. Retrieved July 08, 2015, from http://www.hotel-online.com/press_releases/release/global-hotel-ranking-2015a-second-chinese-operator-climbs-into-the-top-10.

Hotels. (2015). Hotels 325 Rank 2014. Retrieved July 08, 2015, from http://www.hotelsmag.com/Search/Results/?SearchTerm=franchising\&SectionI $\operatorname{Ds}[0]=2 \& \operatorname{SectionIDs}[1]=12 \& \operatorname{SectionIDs}[2]=7$. 
Keup, E. J., and Keup, P. (2012). Franchise Bible, Entrepreneur Press, USA.

Khan, M. A. (1999). Restaurant Franchising, John Wiley \& Sons, USA.

Kırca, Ç. (1997). Franchise Sözleşmesi, Banka ve Ticaret Hukuku Araştırma Enstitüsü, Ankara.

Kültür ve Turizm Bakanlığı. (2015a). Turizm Geliri: 2012-2015. Retrieved December 14, 2015, from http://yigm.kulturturizm.gov.tr/TR,72942/turizm-gelir-gider-veortalama-harcama.html.

Lashley, C. (2000). Empowered Franchisees. Inside C. Lashley and A. Morrison (Eds.), Franchising Hospitality Services (pp. 92-113), Butterworth-Heinemann, Great Britain.

Nart, S. (2005). Türkiye'de Franchising Sisteminin Gelişimi ve Franchise Alan Girişimcilerin İş Memnuniyeti Belirleyicilerinin Analizi Üzerine Bir Araştırma, Kocaeli Üniversitesi Sosyal Bilimler Enstitüsü Dergisi, Vol. 10, No. 2, 123-149.

Marriott. (2015). About Marriott International. Retrieved December 30, 2015, from http://www.marriott.com/marriott/aboutmarriott.mi.

Norman, J. (2006). What No One Ever Tells You about Franchising: Real-Life Franchising Advice from 101 Successful Franchisors and Franchisees, Kaplan Publishing, USA.

Pender, L. (2000). Travel Trade and Transport. Inside C. Lashley and A. Morrison (Eds.), Franchising Hospitality Services (pp. 219-243), Butterworth-Heinemann, Great Britain.

Rushmore, S., and Bagley, E. (2014). 2014 United States Hotel Franchise Fee Guide, HVS, USA.

Saban, N. (1997). Franchising ve Vergilendirme, Beta, İstanbul.

Sharpley, R. (2004). Sustainability: a Barrier to Tourism Development. Inside R. Sharpley and D. J. Telfer (Eds.), Tourism and Development Concepts and Issues (pp. 319-337), Channel View, Clevedon.

Sherman, A. J. (2004). Franchising and Licensing: Two Powerful Ways to Grow Your Business in an Economy, American Management Association, USA.

Starwood Hotels. (2015). Company Overview. Retrieved December 30, 2015, from http://www.starwoodhotels.com/corporate/about/index.html.

Şoğur, M. (1993). İşletme Sistemi Olarak Franchising, Der, İstanbul.

Taylor, S. (2000a). An Introduction. Inside C. Lashley and A. Morrison (Eds.), Franchising Hospitality Services (pp. 3-21), Butterworth-Heinemann, Great Britain.

Taylor, S. (2000b). Hotels. Inside C. Lashley and A. Morrison (Eds.), Franchising Hospitality Services (pp. 170-191), Butterworth-Heinemann, Great Britain.

Türkiye'de Yabancı Marka Sayısı da Otel Grubu da Hızla Artıyor. (2014). Turizm ve Yatırım Dergisi, No. 26, 8-18.

Türkiye'de Zincir ve Grup Oteller. (2012). Resort Dergisi, No. 117, 6-52. 
Türksoy, S. S., Kaygalak, S., and Koçak, N. (2013). Uluslararası Otel İşletmelerinin Büyüme Stratejileri: Hilton Worldwide Türkiye Örneği, İşletme Fakültesi Dergisi, Vol. 4, No. 2, 89-108.

World Tourism Organisation. (2015a). Why Tourism. Retrieved January 27, 2015, from http://www2.unwto.org/content/why-tourism.

World Tourism Organisation. (2015b). Tourism Highlights 2014 Edition. Retrieved May 04, 2015, from http://www.e-unwto.org/doi/pdf/10.18111/9789284416226.

World Tourism Organisation. (2015c). Tourism Highlights 2015 Edition. Retrieved July 01, 2015, from http://www.e-unwto.org/doi/pdf/10.18111/9789284416899.

Wyndham Worldwide. (2015). Company Backgrounder. Retrieved December 24, 2015, from

https://whgcomm.box.com/shared/static/tuxvrbxg1kbx4htznanyg5bd8sdcqm2c.p df. 